\title{
Reviewing the Viability of Renewable Energy in Community Electrification: The Case of Remote Western Australian Communities
}

\author{
Liam Byrnes $^{1, \mathrm{a}, \mathrm{b}}$, Colin Brown ${ }^{\mathrm{a}}$, and Liam Wagner ${ }^{\mathrm{b}}$, John Foster $^{\mathrm{b}}$ \\ ${ }^{a}$ School of Agriculture and Food Sciences, The University of Queensland, St Lucia, Qld, 4072, \\ Australia \\ ${ }^{\mathrm{b}}$ Energy Economics and Management Group, School of Economics, The University of Queensland, \\ St Lucia, Qld, 4072, Australia
}

\begin{abstract}
Governments and utilities are struggling to respond to the increasing costs of energy supply in remote networks while still meeting social objectives of access and availability. Due to vast distances and sparse population, remote Australian communities are generally electrified by distributed networks using diesel generation. This is expensive, environmentally damaging and fails to exploit vast renewable resources available. These communities are often regarded as "low hanging fruit" from a renewable energy deployment perspective. This paper examines why picking that fruit is not straightforward. In Western Australia, the local electricity distribution utility responsible for remote networks, developed a scheme to incentivise renewable energy deployment in remote communities. This scheme aims to facilitate renewable energy deployment from the "bottom up" by providing a feed-in tariff capped at $\$ 0.50 / \mathrm{kWh}$, to reduce the supply cost and environmental damage from diesel generation. This incentive is designed to encourage communities to fund installation. However, to date, there has been limited deployment of renewables in remote communities. The viability of renewable energy in three indigenous communities in the Kimberley region of Western Australia all connected to isolated, diesel powered networks is assessed. Both the potential benefits that can arise across remote communities as well as the barriers to deployment are considered. Renewable energy installation is found to benefit the utility but can also benefit communities subject to their cost of capital and to the imposition of connection charges. However a range of barriers are frustrating deployment and a dynamic and adaptive approach that recognises local challenges and provides the communities with a pathway to installation is needed.
\end{abstract}

\section{Introduction}

Remote communities are characterised by geographical remoteness, dispersed consumers, low consumption, high supply and maintenance costs, and limited ability to pay and their electrification is a persistent challenge throughout the world. It is [1, 2]. Conventional electrification approaches such as grid extension are not financially viable. Depending on the amount of electricity required, existing approaches range from very small PV systems to gas powered microgrids. Renewable energy has the potential to make a major contribution to addressing rural electrification challenges.

The literature is replete with studies examining rural electrification and barriers to renewable energy deployment. These barriers can be categorised into three groups. The first group are institutional barriers including: policy/regulatory barriers such as short-term policy horizons [3-5]; the extent of separation between energy policy and social/environmental objectives [3, 4]; a lack of political will to effect change [3, 4]; and a lack of institutional (utility and government) experience with different technologies and electrification approaches [3]. The second group are financial barriers relating to: capital availability for the high upfront cost of renewable energy technologies [6-8]; the extent to which the existing cost of energy excludes externalities; access to markets [3, 4] and subsidies. The third group are "other barriers" that include: access and understanding of information and

\footnotetext{
${ }^{1}$ Corresponding author: Liam Byrnes, L.byrnes@uq.edu.au, School of Agriculture and Food Sciences, St Lucia Brisbane QLD, 4072 Australia. Tel:+617 3365 1171. Fax: +61 733651177
} 
technological barriers [3]; capacity to progress from preliminary project preparation (such as early assessment of suitability); regulatory frameworks; community consultation requirements [9]; uncertainty; project timeframes; and absence of effective systematic decision making approaches [3, 9]. These barriers can be difficult to overcome without significant investment of financial and human capital. Much of the literature has focused on developing countries and the connection of electricity for the first time [10-15], or the adaptation of existing systems to renewable energy (both on- and offgrid) [10, 11, 16-18].

These challenges are not unique to developed or developing countries. Australia possesses substantial natural energy resources and established electricity infrastructure with $90 \%$ of the population living in urban areas in 2011[19] and 99.9\% of households having access to electricity [20]. The majority of the population receives electricity via large centralised electricity grids that service major cities and towns powered by coal and gas generators, though the generation mix is transitioning away from coal towards gas and renewables [21]. High urbanisation means that electrification in rural areas can be challenging due to low population density and the vast geographical area. Regional and remote communities are generally connected to long Single Wire Earth Return (SWER) lines, or are entirely isolated from the grid and powered by diesel generators. These communities are generally more disadvantaged [22] and, despite existing infrastructure, face energy access challenges associated with their ability to pay.

The Kimberley region is located in northern Western Australia and covers an area of $420,000 \mathrm{~km}^{2}$ with a population of around 35,000 people $\left(0.083\right.$ persons per $\left.\mathrm{km}^{2}\right)$ [23, 24]. As uniform electricity tariffs exist for all residents and most businesses in Western Australia, the local supply cost is significantly less than the applicable tariff for remote communities. The difference between local supply cost and tariffs is borne first by the utility and ultimately by taxpayers and urban electricity consumers.

Table 1 outlines key characteristics of the three communities examined ${ }^{2}$. Two communities are grouped together because that is how they appear in the census information. Community 1 has its own distribution network, while Communities 2 and 3 share a network. Diesel generation is the existing source of electricity for both networks. No renewable energy was installed at the time of research, though there were a small number of solar hot water systems. The Scheme represents an attempt by the government owned distribution network utility (Horizon) to have a framework more reflective of local challenges and drivers. Strong institutional frameworks have been recognised as an integral component of facilitating new electrification projects [25].

\begin{tabular}{|l|r|r|}
\hline & Community 1 & Communities 2 \& 3 \\
\hline Total population & 334 & 245 \\
\hline Total Occupied Private Dwellings & 72 & 58 \\
\hline Males (\% of population) & $171(51.2 \%)$ & $126(51.4 \%)$ \\
\hline Females (\% of population) & $163(48.8 \%)$ & $119(48.6 \%)$ \\
\hline Median Age & 21 years & 24 years \\
\hline $\begin{array}{l}\text { Aboriginal or Torres Strait Islander (\% of } \\
\text { population) }\end{array}$ & $303(90.7 \%)$ & $204(83.3 \%)$ \\
\hline $\begin{array}{l}\text { Same usual address 1 year ago (\% of } \\
\text { population) }\end{array}$ & $273(86.7 \%)$ & $206(89.2 \%)$ \\
\hline Average household size (people) & 3.9 & 3.4 \\
\hline Households Rented (\% of population) & $66(100 \%)$ & $46(93.9 \%)$ \\
\hline $\begin{array}{l}\text { Buildings owned by State or Territory } \\
\text { Housing Authority (\% of total) }\end{array}$ & $14(21.2 \%)$ & $36(78.3 \%)$ \\
\hline
\end{tabular}

\footnotetext{
${ }^{2}$ Due to the nature of these communities, it may be possible to identify some respondents if community names are not anonymised. Names of the communities have been anonymised due to concerns about the potential to identify particular respondents.
} 


\begin{tabular}{|l|r|r|} 
Other landlord type (\% of total) & $52(78.8 \%)$ & $10(21.7 \%)$ \\
\hline Median total household income (\$/weekly) & $\$ 949$ & $\$ 755$ \\
\hline Median rent (\$/weekly)** & $\$ 95$ & $\$ 53$ \\
\hline
\end{tabular}

Table 1: Key community characteristics

** Residents reported that rents were being increased at the time of interviews

Source: $[23,24]$

The study is undertaken in the context of a utility led buyback scheme that aims to incentivise communities to install renewable energy in remote, high cost, distributed networks. To date there has been limited deployment of renewable energy, particularly in remote Kimberley indigenous communities. The buyback scheme ("the Scheme") adopts a bottom-up approach to renewable energy deployment where the "buyback" enables Horizon to share savings resulting from reduced local supply cost with communities that install renewable energy. The Scheme requires installations to be connected behind a demand node so that electricity generated is first used at a demand node (such as a house) and only excess electricity is exported. The buyback rate is intended to be linked to the cost of supply and reviewed annually though the rate has not changed since the Scheme's inception in July 2012. Rates range between $\$ 0.10 / \mathrm{kWh}$ to $\$ 0.50 / \mathrm{kWh}$ depending on remoteness and the utility's supply cost. All are eligible for a buyback of $\$ 0.50 / \mathrm{kWh}$ which represents a premium of approximately $\$ 0.23 / \mathrm{kWh}$ over the residential tariff, and $\$ 0.20 / \mathrm{kWh}$ over the applicable commercial tariff [26, 27]. The total available hosting capacity for each network is $262 \mathrm{KW}$.

This paper builds on existing literature by examining remote communities with established electricity use that share many characteristics with rural communities in developed and developing countries. The insights gained highlight the importance of local barriers and benefits and the role of government incentives in shaping stakeholder responses to renewable energy deployment in remote networks.

After providing the background for the study in Section 3, the methodology is outlined in Section 4. A financial analysis is reported in Section 5, with the barriers and benefits resulting impacting deployment covered in Sections 6 and 7. Implications of the research are discussed in Section 8. Together this enables an understanding of the potential for renewable energy deployment.

\section{Methodology}

Research was undertaken in connection with Horizon, the distribution utility that designed and operates the Scheme. A series of semi-structured interviews to undertake "conversations with a purpose" $[28,29]$ were undertaken in the three communities examined. The three communities were selected due to their location, eligibility for the maximum buyback payable, lack of existing deployment and availability of local support from Horizon. Due to the contextual nature of the data sought, the interviews were designed to draw out local knowledge and understanding. This enabled depth, nuance and complexity to be captured and helped build more rounded data [29]. Consequently, different questions were at times asked of different interviewees to generate situational knowledge with all interviewees. Interviews were conducted with key informants including local Aboriginal Corporations ("Corporations”), other key community representatives and local business managers. Using data obtained through semi-structured interviews, qualitative analysis is undertaken to identify barriers and benefits and examine how the impact deployment of renewables.

Corporations play a critical role in communities and governance and own the local businesses. They operate a participatory decision making model and regard their key responsibility as improving the livelihoods of the community as a whole. A cost benefit analysis (CBA) is used to examine whether there is a financial incentive for communities to deploy renewables. The underlying theoretical framework of CBA is established as are the controversies regarding attempts to measure and compare economic welfare [30, 31]. Levelised cost of energy (LCOE) is used to measure the cost of renewable and diesel generation. LCOE captures the total lifetime costs and provides a comparable financial metric in dollars per unit of energy ( $\$ / \mathrm{MWh})$ that enables comparison between technologies. [32] outline the key assumptions and frameworks underpinning LCOE. The LCOE model used is adapted from [33] which builds on the studies of [34-37]. 


\section{Financial Analysis}

\section{Assessing costs}

The LCOE of solar technologies and diesel generators are assessed. Non-solar renewable energy sources are excluded due to a lack of available resources (wind, biomass and geothermal) or immaturity (wave and tidal).

Data used is primarily sourced from [38, 39]. Following consultations with installers, local cost estimates could only be obtained for fixed tilt PV and for "generation management" and "PV remote area upper limit" (explained below). Industry estimates are necessary because of the lack of renewable energy deployment in remote communities. Generation management is a new technology required by the utility once installed capacity is $>20 \mathrm{~kW}$ in the communities examined. It provides 15 minutes of storage to smooth intermittent generation. Following consultation with installers, a capital cost of $\$ 2.25 / \mathrm{W}$ of installed solar PV is used and added to the technology capital cost consistent with industry practice. Local hourly solar and temperature data is sourced for 2004 to 2013 from the Australian Bureau of Meteorology. For PV, solar data a coefficient of -.0045 is applied to solar production for every degree above $25^{\circ} \mathrm{C}$ consistent with other studies [40].

Three different cost of capital scenarios are applied to a $20 \mathrm{~kW}$ and $262 \mathrm{~kW}$ system as shown in Table 2. The two system sizes represent the maximum unmanaged connection possible $(20 \mathrm{~kW})$, and the maximum connection allowable $(262 \mathrm{~kW})$. Due to their proximity and similar characteristics, the same scenarios and sizes are applied to all communities. Thermal technologies have much higher capacity factors and consequently satisfy more of the total demand. However, fixed tilt PV is the most likely technology to be deployed due to its cost, maturity and suitability for rooftops (thus being easier to connect behind a demand node).

Scenario 1 reflects installation by a community or small investor where the debt/equity split shows the limited equity resources available and dependence on external funds. The market risk premium of $6 \%$ is typical of projects of this type and the debt basis point premium reflects a conservative 10 year bond rate. Scenario 2 reflects where a community obtains a grant equivalent to $70 \%$ of the project costs, with the remainder sourced from debt. A 70\% grant was identified as the upper limit of grant funding based on prior experience and discussions with government agencies such as Indigenous Business Australia (IBA).

\begin{tabular}{|l|r|r|r|}
\hline Component & \multicolumn{2}{|l|}{ Scenario 1 } & \multicolumn{2}{|l|}{ Scenario 2 } & \multicolumn{2}{|c|}{ Scenario 3 } \\
\hline Liabilities & \multicolumn{2}{|c|}{} \\
\hline Debt & $80.00 \%$ & $30.00 \%$ & $60.00 \%$ \\
\hline Equity & $20.00 \%$ & $70.00 \%$ & $40.00 \%$ \\
\hline Risk free Rate of return (RoR) & $6.00 \%$ & $6.00 \%$ & $6.00 \%$ \\
\hline Market risk premium & $6.00 \%$ & & $8.00 \%$ \\
\hline Market RoR & $12.00 \%$ & $6.00 \%$ & $14.00 \%$ \\
\hline Corporate tax rate & $30.00 \%$ & $30.00 \%$ & $30.00 \%$ \\
\hline Effective tax rate & $22.50 \%$ & $22.50 \%$ & $22.50 \%$ \\
\hline Debt basis point Premium & $4.00 \%$ & $4.00 \%$ & $5.00 \%$ \\
\hline Cost of debt & $10.00 \%$ & $10.00 \%$ & $11.00 \%$ \\
\hline Gamma & 0.5 & 0.5 & 0.5 \\
\hline Asset Beta & 0.8 & 0.8 & 0.8 \\
\hline Debt beta & 0.16 & 0.16 & 0.16 \\
\hline Equity Beta & 1.75 & 1.75 & 1.75 \\
\hline Required return on equity CAPM & $16.50 \%$ & $6.00 \%$ & $20.00 \%$ \\
\hline Inflation & $2.50 \%$ & $2.50 \%$ & $2.50 \%$ \\
\hline
\end{tabular}




\begin{tabular}{|l|r|r|r|} 
WACC Post-Tax nominal & $9.08 \%$ & $5.99 \%$ & $12.10 \%$ \\
\hline WACC Post-Tax real & $6.42 \%$ & $3.41 \%$ & $9.37 \%$ \\
\hline
\end{tabular}

\section{Table 2: LCOE WACC inputs}

Scenario 3 reflects a commercial debt to equity mix for energy projects in small communities. The market risk premium is increased to $8 \%$ while the debt premium is increased to $5 \%$. These values better reflect equity and financier risk aversion to commercial renewables projects in remote communities. A CAPM of $20 \%$ is consistent with the CAPM likely to be required by investors including IBA (before any concession was applied).

An additional fixed operating expense is added. This cost equates to a total additional fixed operating and maintenance cost of $\$ 41,528.45$ p.a. and reflects the cost of an electrician who is required to travel to each installation weekly. Travel from the nearest major town is included. The factors included in the LCOE model are shown in Figure 2.

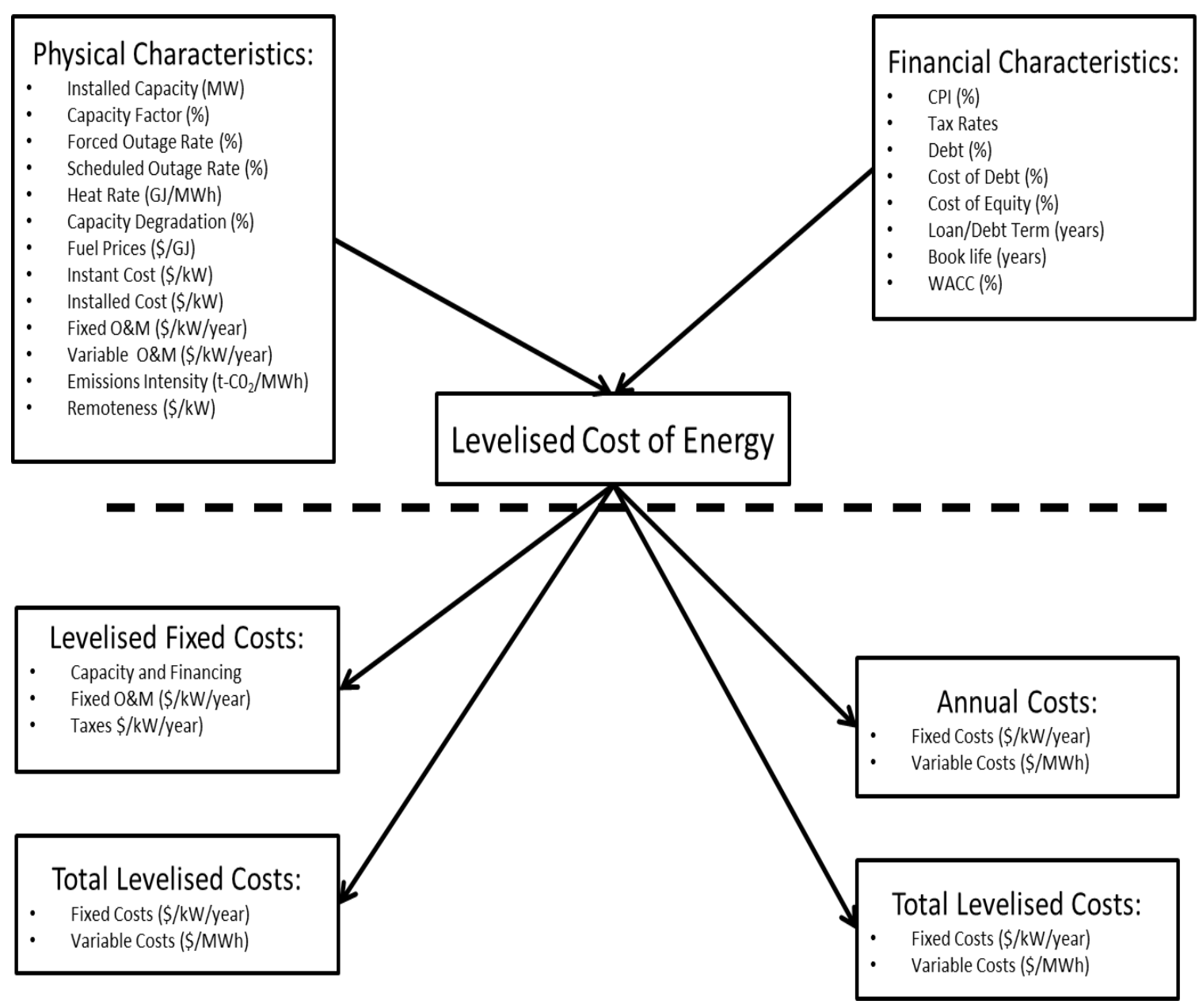

Figure 1: LCOE inputs

Source: Adapted from [33]

Equation 1 sets out the function for levelised cost (sourced from [33]) for each generator $j$. The parameters are outlined in Table 3. 


$$
\begin{gathered}
\operatorname{LCOE}_{j}=\left(\frac{\sum_{t=1}^{n}\left(\frac{O C(t)_{j}+F u e l(t)_{r}+O \& M(t)_{r}+C M(t)_{r}+E L(t)_{r}-R E(t)_{r}}{(1+W A C C)^{t}}\right)+\text { CAPEX }_{j}}{\frac{\sum_{t=1}^{n}\left(\frac{\text { Size }_{j} * C F_{j} * 8760 *\left(1-A u x_{j}\right)}{1000}\right) * \operatorname{CPI}\left((t)_{r}\right.}{(1+W A C C)^{t}}}\right) \\
=\sum_{t=1}^{n}\left(\frac{\left(\frac{T O C(t)_{j}}{(1+W A C C)^{t}}\right)+C A P E X_{j}}{\frac{\left(\sum_{t=1}^{n}\left(S O(t)_{j}\right) * C P I(t)_{R}\right.}{(1+W A C C)^{t}}}\right)
\end{gathered}
$$

\begin{tabular}{|c|c|}
\hline Total costs & $\operatorname{TOC}(t)_{j}=\mathrm{Fuel}(t)_{r}+O \& M(t)_{r}+C M(t)_{r}+E L(t)_{r}-R E(t)_{r}$ \\
\hline $\begin{array}{l}\text { Fixed and Variable } \\
\text { operating and } \\
\text { maintenance costs }\end{array}$ & $\begin{array}{l}\mathrm{O} \& \mathrm{M}(\mathrm{t}) \mathrm{j}=\operatorname{VOM}(t)_{j}+\operatorname{FOM}(t)_{j} \\
\text { Where: } \\
\left.\operatorname{VOM}(t+1)_{j}^{E}\right)_{j}=V O C_{t} * \mathrm{SO}(t)_{j} * \mathrm{CPI}\left((t)_{C}\right. \\
\text { incorporates the initial cost of construction } V O C_{j} \text { per MW, increasing by } \\
\operatorname{CPI}\left((t)_{C} \text { incorporating the sent out energy } \mathrm{SO}(t)_{j}\right. \\
\operatorname{VOC}(t)_{j}^{E}=\operatorname{VOC}(t)_{j} * E \\
\mathrm{FOM}(t+1)_{j}^{E}=F O M_{t} * C P I(t)_{C} \\
\mathrm{FOM}(t)_{j}^{E}=F O M_{t} * \mathrm{E}\end{array}$ \\
\hline $\begin{array}{l}\text { Technology depletion } \\
\text { costs }\end{array}$ & $C M(t)_{j}^{E}=\left(\frac{C F_{j}^{E} * \text { Capex }_{j}^{E} * C P I(t)_{C}}{\text { Life }_{j}} *\right)$ \\
\hline Fuel cost & $\operatorname{Fuel}(t)_{j}^{E}=\left(\frac{\left(H R_{j} * E\right) * C F_{j}^{E} * F C(t)_{j}}{1000}\right) * S O(t)_{j}^{E} * C P I(t)_{C}$ \\
\hline Capital Costs & Capex $_{j}$ \\
\hline Capacity Factor & $C F_{j}^{E}$ \\
\hline Sent Out Energy & $\begin{array}{l}\mathrm{SO}(t)_{j}=\left(\frac{\operatorname{size}_{j} * C F_{j} * 8760 *\left(1-A u x_{j}\right)}{1000}\right) \\
\text { Where, the revenue inflation rate to output generated of the sent out energy } \\
\text { is: } \\
\mathrm{SOR}(t)_{j}=\mathrm{SO}\left((t)_{j} * \mathrm{CPI}\left((t)_{r}\right.\right.\end{array}$ \\
\hline $\begin{array}{l}\text { Carbon Emissions } \\
\text { Liability }\end{array}$ & $\begin{array}{l}\mathrm{EL}(t)_{j}=\mathrm{SO}(t)_{j} * E I F_{j} * C_{t} * \mathrm{CPI}(t)_{r} * C L_{j} \\
\text { Where: } \\
E I F_{j}=\text { the emissions intensity of any generation technology } \\
C L_{j}=\text { the emissions liability } \\
C_{t}=\text { the carbon price at time } t\end{array}$ \\
\hline $\begin{array}{l}\text { Payments under } \\
\text { renewable energy } \\
\text { scheme }\end{array}$ & $\begin{array}{l}R E(t)_{j}=\mathrm{SO}(t)_{j} * R E C_{t} * \mathrm{CPI}(t)_{r} * R E E_{j} \\
\text { Where: } \\
R E C_{t}=\text { the renewable energy certificate price at time } t \\
R E E_{j}=\{0,1\} \text { which reflects a generation types eligibility under the Federal } \\
\text { Government Scheme }\end{array}$ \\
\hline
\end{tabular}

Where:

Table 3: LCOE Parameters

To calculate capacity factors for fixed tilt PV, the optimal fixed tilt angle is determined using the method as follows:

Firstly we calculate the maximum annual solar insolation $I$ such that, 


$$
I=\sum_{q}^{Q} \text { Smodule }[\text { seas }]_{Q}
$$

such that Smodule $[\text { seas }]_{Q}$

$$
\begin{gathered}
\text { Smodule }[\text { seas }]_{Q}=\sum_{t=0}^{23} \text { Smodule }[\text { seas }]_{Q_{t}} \\
=\frac{\text { Shorizontal }_{t} * \sin \left(\alpha_{t}+\beta\right)}{\sin \left(\alpha_{t}\right)}
\end{gathered}
$$

is the seasonal average daily insolation. The insolation incident $I_{m}$ with the installed module is given as:

$$
\begin{gathered}
I_{m}=\sum_{t=0}^{23} \text { Smodule }_{t} \\
=\frac{\text { Shorizontal }_{t} * \sin \left(\alpha_{t}+\beta\right)}{\sin \left(\alpha_{t}\right)}
\end{gathered}
$$

Where:

$Q=$ quarter of the year (equivalent to seasons Summer, Autumn, Winter, Spring)

$t=$ hour of the day

Shorizontal $_{t}=$ global horizontal insolation

$\alpha_{t}=$ Altitude of the sun at time $t^{3}$

$\beta=$ tilt angle of the panels where $0 \leq \beta \leq 90$

Calculated LCOE for different solar thermal technologies appear in Table 5. Technologies with attached storage do not require generation management. The remote area upper limit includes generation management as the estimates from industry only relate to managed connections. There is no change in LCOE for the different system sizes due to the small change in size. Transmission Use of System and Distribution Use of System charges (TUOS and DUOS) are excluded. TUOS charges are excluded because there is no transmission network. DUOS charges are excluded because the buyback arrangement does not impose a DUOS charge for connections. DUOS charges are generally only applied to larger commercial installations. If the Scheme is altered, it is unlikely DUOS charges would be applied due to the community stakeholders and the small size of connection.

\section{LCOE of renewable technologies}

Table 4 sets out key inputs into the LCOE analysis

\footnotetext{
${ }^{3} \alpha_{t}$ was obtained from Geoscience Australia via http://www.ga.gov.au/geodesy/astro/smpos.jsp
} 


\begin{tabular}{|c|c|c|c|c|c|c|c|c|}
\hline & $\begin{array}{l}\text { Solar } \\
\text { Thermal - } \\
\text { Parabolic } \\
\text { Trough w } \\
\text { 6hrs Storage }\end{array}$ & $\begin{array}{l}\text { Solar Thermal } \\
\text { - Parabolic } \\
\text { Trough w/out } \\
\text { Storage }\end{array}$ & $\begin{array}{l}\text { Solar } \\
\text { Thermal - } \\
\text { Central } \\
\text { Receiver w } \\
\text { 6hrs Storage }\end{array}$ & $\begin{array}{l}\text { Solar Thermal } \\
\text { - Central } \\
\text { Receiver w/out } \\
\text { Storage }\end{array}$ & $\begin{array}{l}\text { Photovoltaic - } \\
\text { Fixed Tilt }\end{array}$ & $\begin{array}{l}\text { Photovoltaic - } \\
\text { Single Axis } \\
\text { Tracking }\end{array}$ & $\begin{array}{l}\text { Photovoltaic - } \\
\text { Two Axis } \\
\text { Tracking }\end{array}$ & $\begin{array}{l}\text { Photovoltaic } \\
\text { - Fixed Tilt - } \\
\text { Remote } \\
\text { Area Upper } \\
\text { Limit } \\
\end{array}$ \\
\hline Conversion efficiency & $26 \%$ & $26 \%$ & $31 \%$ & $31 \%$ & $15 \%$ & $17 \%$ & $19 \%$ & $15 \%$ \\
\hline Inverter efficiency & $98 \%$ & $98 \%$ & $98 \%$ & $98 \%$ & $98 \%$ & $98 \%$ & $98 \%$ & $98 \%$ \\
\hline $\begin{array}{l}\text { Capex }(\$ / k W \\
\text { installed) with } \\
\text { generation } \\
\text { management }\end{array}$ & $\$ 8,792$ & $\$ 8,097$ & $\$ 7,929$ & $\$ 8,050$ & $\$ 4,706$ & $\$ 6,042$ & $\$ 7,564$ & $\$ 5,000$ \\
\hline $\begin{array}{l}\text { Capital Cost (\$/kW } \\
\text { installed) without } \\
\text { generation } \\
\text { management }\end{array}$ & $\$ 8,792$ & $\$ 5,847$ & $\$ 7,929$ & $\$ 5,800$ & $\$ 2,456$ & $\$ 3,792$ & $\$ 5,314$ & $\$ 5,000$ \\
\hline Capacity Factor & $45.05 \%$ & $36.04 \%$ & $40.98 \%$ & $32.78 \%$ & $20.00 \%$ & $23.85 \%$ & $27.55 \%$ & $20.00 \%$ \\
\hline VOM (\$/kW/ year) & 40.69 & 56.39 & 28.45 & 38.37 & 13.4 & 14.1 & 17.3 & 13.4 \\
\hline FOM (\$/kW/ year) & 72.38 & 59.18 & 71.37 & 58.29 & 25 & 30 & 39 & 25 \\
\hline
\end{tabular}

Table 4: Key Inputs into LCOE 


\begin{tabular}{|c|c|c|c|c|c|c|c|c|c|}
\hline \multicolumn{2}{|c|}{ Technology } & $\begin{array}{l}\text { Solar } \\
\text { Thermal - } \\
\text { Parabolic } \\
\text { Trough w } \\
\text { 6hrs Storage }\end{array}$ & $\begin{array}{l}\text { Solar Thermal } \\
\text { - Parabolic } \\
\text { Trough w/out } \\
\text { Storage }\end{array}$ & $\begin{array}{l}\text { Solar } \\
\text { Thermal - } \\
\text { Central } \\
\text { Receiver w } \\
\text { 6hrs Storage }\end{array}$ & $\begin{array}{l}\text { Solar } \\
\text { Thermal - } \\
\text { Central } \\
\text { Receiver } \\
\text { w/out Storage }\end{array}$ & $\begin{array}{l}\text { Photovoltaic - } \\
\text { Fixed Tilt }\end{array}$ & $\begin{array}{l}\text { Photovoltaic - } \\
\text { Single Axis } \\
\text { Tracking }\end{array}$ & $\begin{array}{l}\text { Photovoltaic - } \\
\text { Twin Axis } \\
\text { Tracking }\end{array}$ & $\begin{array}{l}\text { Photovoltaic - } \\
\text { Fixed Tilt - } \\
\text { Remote area } \\
\text { upper limit } \\
\text { (w/g.mgmt) }\end{array}$ \\
\hline \multicolumn{10}{|c|}{ Without Generation Management (unless otherwise noted) } \\
\hline \multirow{3}{*}{ Scenario 1} & Fixed & $\$ 230.80$ & $\$ 168.80$ & $\$ 236.90$ & $\$ 207.10$ & $\$ 136.10$ & $\$ 175.00$ & $\$ 207.40$ & $\$ 338.80$ \\
\hline & Variable & $\$ 49.30$ & $\$ 68.30$ & $\$ 34.50$ & $\$ 44.80$ & $\$ 14.50$ & $\$ 16.10$ & $\$ 19.70$ & $\$ 14.50$ \\
\hline & Total & $\$ 280.10$ & $\$ 237.10$ & $\$ 271.40$ & $\$ 251.90$ & $\$ 150.60$ & $\$ 191.10$ & $\$ 227.10$ & $\$ 353.30$ \\
\hline \multirow{3}{*}{ Scenario 2} & Fixed & $\$ 175.70$ & $\$ 131.00$ & $\$ 180.70$ & $\$ 159.10$ & $\$ 108.50$ & $\$ 137.40$ & $\$ 161.70$ & $\$ 276.80$ \\
\hline & Variable & $\$ 49.60$ & $\$ 68.70$ & $\$ 34.70$ & $\$ 45.00$ & $\$ 14.60$ & $\$ 16.20$ & $\$ 19.90$ & $\$ 14.60$ \\
\hline & Total & $\$ 225.30$ & $\$ 199.70$ & $\$ 215.40$ & $\$ 204.10$ & $\$ 123.10$ & $\$ 153.60$ & $\$ 181.60$ & $\$ 291.30$ \\
\hline \multirow{3}{*}{ Scenario 3} & Fixed & $\$ 296.70$ & $\$ 214.00$ & $\$ 304.10$ & $\$ 264.60$ & $\$ 167.90$ & $\$ 218.40$ & $\$ 260.10$ & $\$ 409.20$ \\
\hline & Variable & $\$ 49.00$ & $\$ 68.00$ & $\$ 34.30$ & $\$ 44.50$ & $\$ 14.40$ & $\$ 16.00$ & $\$ 19.60$ & $\$ 14.40$ \\
\hline & Total & $\$ 345.70$ & $\$ 282.00$ & $\$ 338.40$ & $\$ 309.10$ & $\$ 182.40$ & $\$ 234.40$ & $\$ 279.70$ & $\$ 423.60$ \\
\hline \multicolumn{2}{|c|}{ Capacity Factor (\%) } & $45.05 \%$ & $36.04 \%$ & $40.98 \%$ & $32.78 \%$ & $20.00 \%$ & $23.85 \%$ & $27.55 \%$ & $20.00 \%$ \\
\hline \multicolumn{10}{|c|}{ With Generation Management (unless otherwise noted) } \\
\hline \multirow{3}{*}{ Scenario 1} & Fixed & $\$ 230.80$ & $\$ 233.06$ & $\$ 236.90$ & $\$ 275.04$ & $\$ 302.14$ & $\$ 337.69$ & $\$ 364.70$ & $\$ 338.78$ \\
\hline & Variable & $\$ 49.30$ & $\$ 68.33$ & $\$ 34.47$ & $\$ 44.78$ & $\$ 14.50$ & $\$ 16.06$ & $\$ 19.70$ & $\$ 14.50$ \\
\hline & Total & $\$ 280.10$ & $\$ 301.39$ & $\$ 271.37$ & $\$ 319.82$ & $\$ 316.64$ & $\$ 353.75$ & $\$ 384.40$ & $\$ 353.27$ \\
\hline \multirow{3}{*}{ Scenario 2} & Fixed & $\$ 175.71$ & $\$ 177.59$ & $\$ 180.68$ & $\$ 208.29$ & $\$ 244.23$ & $\$ 271.94$ & $\$ 293.42$ & $\$ 276.76$ \\
\hline & Variable & $\$ 49.59$ & $\$ 68.72$ & $\$ 34.67$ & $\$ 45.04$ & $\$ 14.58$ & $\$ 16.15$ & $\$ 19.81$ & $\$ 14.58$ \\
\hline & Total & $\$ 225.29$ & $\$ 246.31$ & $\$ 215.36$ & $\$ 253.32$ & $\$ 258.81$ & $\$ 288.09$ & $\$ 313.23$ & $\$ 291.34$ \\
\hline \multirow{3}{*}{ Scenario 3} & Fixed & $\$ 296.67$ & $\$ 299.40$ & $\$ 304.13$ & $\$ 354.87$ & $\$ 367.97$ & $\$ 412.42$ & $\$ 445.69$ & $\$ 409.21$ \\
\hline & Variable & $\$ 49.05$ & $\$ 67.97$ & $\$ 34.29$ & $\$ 44.55$ & $\$ 14.42$ & $\$ 15.97$ & $\$ 19.60$ & $\$ 14.42$ \\
\hline & Total & $\$ 345.72$ & $\$ 367.37$ & $\$ 338.42$ & $\$ 399.41$ & $\$ 382.40$ & $\$ 428.39$ & $\$ 465.29$ & $\$ 423.64$ \\
\hline \multicolumn{2}{|c|}{ Capacity Factor (\%) } & $45.05 \%$ & $36.04 \%$ & $40.98 \%$ & $32.78 \%$ & $20.00 \%$ & $23.85 \%$ & $27.55 \%$ & $20.00 \%$ \\
\hline
\end{tabular}

Table 5: LCOE of renewable technologies (\$/MWh) 


\section{LCOE of diesel generation}

The following assumptions are made to calculate the LCOE of diesel generation:

- Diesel generators are $200 \mathrm{~kW}$ with a capacity factor of $70 \%$ and useful life of 7 years.

- The capital maintenance rate is (14.29\%) to reflect the need for total replacement of generators.

- $\quad$ No fuel excise tax is payable (currently $\$ 0.38 /$ litre) because remote generators are exempt.

- The introduction of renewable energy would not substantially impact the capacity factor because each network incorporates multiple generators which can be switched off if necessary.

- The integration of renewable energy does not affect generator life or increase maintenance costs.

Diesel generator LCOE calculations use EIA forecast West Texas Intermediate Crude Oil Price (WTI for three fuel price states for $2015-2040^{4}$ and uses an adapted version of the method used to forecast petrol pump prices in [41]. Calculated LCOE is shown in Table 6.

\begin{tabular}{|c|c|c|c|c|}
\hline \multicolumn{2}{|c|}{ Technology } & $\begin{array}{l}\text { Diesel generator - } \\
\text { High fuel prices }\end{array}$ & $\begin{array}{l}\text { Diesel generator - } \\
\text { Reference fuel prices }\end{array}$ & $\begin{array}{l}\text { Diesel generator - } \\
\text { Low fuel prices }\end{array}$ \\
\hline \multirow{3}{*}{ Scenario 1} & Fixed & $\$ 99.72$ & $\$ 99.72$ & $\$ 99.72$ \\
\hline & Variable & $\$ 596.33$ & $\$ 447.21$ & $\$ 321.08$ \\
\hline & Total & $\$ 696.04$ & $\$ 546.92$ & $\$ 420.80$ \\
\hline \multirow{3}{*}{ Scenario 2} & Fixed & $\$ 99.66$ & $\$ 99.66$ & $\$ 99.66$ \\
\hline & Variable & $\$ 599.26$ & $\$ 454.09$ & $\$ 319.09$ \\
\hline & Total & $\$ 698.92$ & $\$ 553.75$ & $\$ 418.76$ \\
\hline \multirow{3}{*}{ Scenario 3} & Fixed & $\$ 100.30$ & $\$ 100.30$ & $\$ 100.30$ \\
\hline & Variable & $\$ 592.82$ & $\$ 440.90$ & $\$ 322.44$ \\
\hline & Total & $\$ 693.12$ & $\$ 541.20$ & $\$ 422.74$ \\
\hline \multicolumn{2}{|c|}{ Capacity Factor (\%) } & $70.00 \%$ & $70.00 \%$ & $70.00 \%$ \\
\hline
\end{tabular}

Table 6: LCOE diesel generation (\$/MWh)

Diesel generation LCOE is highly sensitive to changes in forecast diesel price but only marginally sensitive to changes in WACC in contrast to solar LCOE which is sensitive to WACC.

\section{Net Benefit/Loss}

Financial viability is assessed from the perspective of the utility and the community to build understanding of the distribution of benefits and costs between the two main stakeholders. The following constraints and assumptions apply:

\section{Constraints}

Maximum hosting capacity without generation management is $20 \mathrm{~kW}$

With generation management, maximum hosting capacity is $262 \mathrm{~kW}$

Renewables must be connected behind a demand point (e.g. Home or business)

\section{Assumptions}

$20 \mathrm{~kW}$ system excludes generation management

$262 \mathrm{~kW}$ system incorporates $20 \mathrm{~kW}$ unmanaged and $242 \mathrm{~kW}$ of managed renewables

Generators are modelled as one generation unit

Buyback price is assumed to be constant at $\$ 0.50 / \mathrm{kWh}$ over the life of the project because:

${ }^{4}$ Available at http://www.eia.gov/forecasts/aeo/index.cfm 
- There is no obligation on the utility to change the buyback price

- During interviews, significant uncertainty about the extent to which communities could rely on the buyback price in the future was expressed. Fixing the price at $\$ 0.50 / \mathrm{kWh}$ erodes the value of the buyback price overtime and is likely to reflect the limited confidence in the continued existence of the buyback potential investors over the project life.

The electricity tariff in 2014 is $\$ 0.29 / \mathrm{kWh}$ representing a combination of residential and small business tariffs.

The electricity tariff increases annually at a conservative rate in line with inflation of $2.5 \%$.

$\mathrm{CO}_{2}$ emissions have not been captured because there is no longer carbon pricing in Australia

$50 \%$ of electricity generated is used at the demand point (the rest is exported). This division reflects

estimates provided by the utility during community information sessions, and public discussions

regarding the Scheme.

There are no land costs.

All figures are calculated over a 20 year useful life.

Table 7: Assumptions

The net benefit is calculated from two distinct perspectives:

From the perspective of the community:

$$
\text { Net Benefit } T_{T}=P V_{T, i}+P V_{T, e a}-L C O E_{T}
$$

And, from the perspective of the utility:

$$
\text { Net Benefit } T_{T}=L C O E_{T, s}-P V_{T, c}-P V_{T, u e}+
$$

Where:

$T=$ renewable technology type

$\mathrm{i}=$ income from the buyback price

$e a=$ Value of electricity avoided

$s=$ diesel fuel scenario

$c=$ cost of the buyback scheme

$u e=$ value of reduction in unpaid debt

unpaid debt $=$ proportion of electricity unpaid in indigenous communities (estimated as 6.93\%) *

value of electricity unsold (based on the average unpaid rate across the network) [42]

Table 8 and Table 9 show the financial benefits from the installation of renewable energy for all technology types and across all scenarios. The higher the diesel fuel price scenario, the greater the benefit to the utility due to the increased diesel costs avoided. The installation of renewables in remote networks enables the utility to save money through reduced supply cost and also provides a hedge against future fuel price increases.

For communities, the only scenario in which they receive a net benefit for all system sizes (and for all technologies) is Scenario 2 where a 70\% capital grant has been provided. If such a grant is unavailable, only fixed tilt and single axis photovoltaic technologies are financially viable for $20 \mathrm{~kW}$ installations (with fixed tilt providing the greatest benefit). The requirement for generation management restricts connections to the unmanaged hosting capacity and imposes costs on the community reducing the incentive to exploit the total hosting capacity.

It is too simplistic to conclude that the utility is monopolising the benefit based on these figures alone. The limited return to the community is a function of the cross-subsidised electricity tariffs that exist. 
If the electricity tariff increases to equal the supply cost, the net benefit to communities would increase and the net benefit to the utility would decrease. This reflects the distorted incentives that arise from uniform tariff policies the implications of which are examined in [43]. However, higher costs would also decrease community capacity to deploy renewables due increased pressure on already limited resources.

\begin{tabular}{|c|c|c|c|c|c|c|}
\hline \multirow{2}{*}{ Net Benefit } & \multicolumn{2}{|c|}{ Scenario 1} & \multicolumn{2}{|c|}{ Scenario 2} & \multicolumn{2}{|c|}{ Scenario 3} \\
\hline & $20 \mathrm{~kW}$ & $262 \mathrm{~kW}$ & $20 \mathrm{~kW}$ & $262 \mathrm{~kW}$ & $20 \mathrm{~kW}$ & $262 \mathrm{~kW}$ \\
\hline \multicolumn{7}{|c|}{ Solar Thermal - Parabolic Trough w/ 6hrs Storage } \\
\hline $\begin{array}{l}\text { Community } \\
\text { Perspective }\end{array}$ & $-\$ 85,542$ & $-\$ 1,120,598$ & $\$ 78,806$ & $\$ 1,032,362$ & $-\$ 237,766$ & $-\$ 3,114,731$ \\
\hline $\begin{array}{l}\text { Utility Perspective } \\
\text { (low fuel scenario) }\end{array}$ & $\$ 303,301$ & $\$ 3,955,382$ & $\$ 220,262$ & $\$ 2,861,227$ & $\$ 361,066$ & $\$ 4,115,467$ \\
\hline $\begin{array}{c}\text { Utility Perspective } \\
\text { (base fuel } \\
\text { scenario) } \\
\end{array}$ & $\$ 482,499$ & $\$ 6,302,876$ & $\$ 412,063$ & $\$ 5,373,826$ & $\$ 529,363$ & $\$ 6,151,862$ \\
\hline $\begin{array}{c}\text { Utility Perspective } \\
\text { (high fuel } \\
\text { scenario) } \\
\end{array}$ & $\$ 694,369$ & $\$ 9,078,372$ & $\$ 618,318$ & $\$ 8,075,767$ & $\$ 745,216$ & $\$ 8,763,685$ \\
\hline \multicolumn{7}{|c|}{ Solar Thermal - Parabolic Trough w/out Storage } \\
\hline $\begin{array}{l}\text { Community } \\
\text { Perspective }\end{array}$ & $-\$ 52,483$ & $-\$ 1,571,743$ & $\$ 68,266$ & $\$ 253,189$ & $-\$ 161,479$ & $-\$ 3,290,111$ \\
\hline $\begin{array}{l}\text { Utility Perspective } \\
\text { (low fuel scenario) }\end{array}$ & $\$ 242,640$ & $\$ 3,164,305$ & $\$ 176,209$ & $\$ 2,288,981$ & $\$ 288,853$ & $\$ 3,772,881$ \\
\hline $\begin{array}{c}\text { Utility Perspective } \\
\text { (base fuel } \\
\text { scenario) } \\
\end{array}$ & $\$ 385,999$ & $\$ 5,042,301$ & $\$ 329,650$ & $\$ 4,299,060$ & $\$ 423,490$ & $\$ 5,536,635$ \\
\hline $\begin{array}{c}\text { Utility Perspective } \\
\text { (high fuel } \\
\text { scenario) } \\
\end{array}$ & $\$ 555,495$ & $\$ 7,262,698$ & $\$ 494,654$ & $\$ 6,460,614$ & $\$ 596,173$ & $\$ 7,798,775$ \\
\hline \multicolumn{7}{|c|}{ Solar Thermal - Central Receiver w 6hrs Storage } \\
\hline $\begin{array}{l}\text { Community } \\
\text { Perspective }\end{array}$ & $-\$ 97,103$ & $-\$ 1,272,055$ & $\$ 59,686$ & $\$ 781,887$ & $-\$ 244,279$ & $-\$ 3,200,060$ \\
\hline $\begin{array}{l}\text { Utility Perspective } \\
\text { (low fuel scenario) }\end{array}$ & $\$ 275,858$ & $\$ 3,053,725$ & $\$ 200,332$ & $\$ 2,061,208$ & $\$ 328,396$ & $\$ 3,743,097$ \\
\hline $\begin{array}{c}\text { Utility Perspective } \\
\text { (base fuel } \\
\text { scenario) } \\
\end{array}$ & $\$ 438,842$ & $\$ 5,025,833$ & $\$ 374,779$ & $\$ 4,172,018$ & $\$ 481,466$ & $\$ 5,595,238$ \\
\hline $\begin{array}{c}\text { Utility Perspective } \\
\text { (high fuel } \\
\text { scenario) } \\
\end{array}$ & $\$ 631,542$ & $\$ 7,357,500$ & $\$ 562,372$ & $\$ 6,441,893$ & $\$ 677,788$ & $\$ 7,970,740$ \\
\hline \multicolumn{7}{|c|}{ Solar Thermal - Central Receiver w/out Storage } \\
\hline $\begin{array}{l}\text { Community } \\
\text { Perspective }\end{array}$ & $-\$ 62,180$ & $-\$ 1,758,751$ & $\$ 55,673$ & $\$ 45,326$ & $-\$ 170,885$ & $-\$ 3,493,711$ \\
\hline $\begin{array}{l}\text { Utility Perspective } \\
\text { (low fuel scenario) }\end{array}$ & $\$ 220,686$ & $\$ 2,442,980$ & $\$ 160,266$ & $\$ 1,648,966$ & $\$ 262,717$ & $\$ 2,994,477$ \\
\hline $\begin{array}{c}\text { Utility Perspective } \\
\text { (base fuel } \\
\text { scenario) } \\
\end{array}$ & $\$ 351,073$ & $\$ 4,020,666$ & $\$ 299,823$ & $\$ 3,337,614$ & $\$ 385,173$ & $\$ 4,476,190$ \\
\hline $\begin{array}{c}\text { Utility Perspective } \\
\text { (high fuel } \\
\text { scenario) } \\
\end{array}$ & $\$ 505,233$ & $\$ 5,886,000$ & $\$ 449,898$ & $\$ 5,153,515$ & $\$ 542,231$ & $\$ 6,376,592$ \\
\hline
\end{tabular}

Table 8: Net Benefit - Solar Thermal Technologies 


\begin{tabular}{|c|c|c|c|c|c|c|}
\hline \multirow{2}{*}{ Net Benefit } & \multicolumn{2}{|c|}{ Scenario 1} & \multicolumn{2}{|c|}{ Scenario 2} & \multicolumn{2}{|c|}{ Scenario 3} \\
\hline & 20 kW & $262 \mathrm{~kW}$ & $20 \mathrm{~kW}$ & $262 \mathrm{~kW}$ & $20 \mathrm{~kW}$ & $262 \mathrm{~kW}$ \\
\hline \multicolumn{7}{|c|}{ Photovoltaic - Fixed tilt } \\
\hline $\begin{array}{l}\text { Community } \\
\text { Perspective }\end{array}$ & $\$ 31,674$ & $-\$ 422,343$ & $\$ 88,891$ & $\$ 367,445$ & $-\$ 16,466$ & $-\$ 1,412,611$ \\
\hline $\begin{array}{l}\text { Utility Perspective } \\
\text { (low fuel scenario) }\end{array}$ & $\$ 136,052$ & $\$ 1,509,018$ & $\$ 99,621$ & $\$ 1,205,415$ & $\$ 161,404$ & $\$ 1,952,985$ \\
\hline $\begin{array}{l}\text { Utility Perspective } \\
\text { (base fuel } \\
\text { scenario) }\end{array}$ & $\$ 215,583$ & $\$ 2,471,338$ & $\$ 184,745$ & $\$ 2,235,417$ & $\$ 236,096$ & $\$ 2,856,765$ \\
\hline $\begin{array}{l}\text { Utility Perspective } \\
\text { (high fuel } \\
\text { scenario) }\end{array}$ & $\$ 309,614$ & $\$ 3,609,110$ & $\$ 276,284$ & $\$ 3,343,037$ & $\$ 331,895$ & $\$ 4,015,927$ \\
\hline \multicolumn{7}{|c|}{ Photovoltaic - Single Axis Tracking } \\
\hline $\begin{array}{l}\text { Community } \\
\text { Perspective }\end{array}$ & $\$ 3,958$ & $-\$ 995,557$ & $\$ 80,598$ & $\$ 189,900$ & $-\$ 63,141$ & $-\$ 2,105,044$ \\
\hline $\begin{array}{l}\text { Utility Perspective } \\
\text { (low fuel scenario) }\end{array}$ & $\$ 162,263$ & $\$ 1,963,388$ & $\$ 118,814$ & $\$ 1,437,646$ & $\$ 192,499$ & $\$ 2,329,240$ \\
\hline $\begin{array}{l}\text { Utility Perspective } \\
\text { (base fuel } \\
\text { scenario) } \\
\end{array}$ & $\$ 257,116$ & $\$ 3,111,105$ & $\$ 220,337$ & $\$ 2,666,083$ & $\$ 281,582$ & $\$ 3,407,138$ \\
\hline $\begin{array}{l}\text { Utility Perspective } \\
\text { (high fuel } \\
\text { scenario) } \\
\end{array}$ & $\$ 369,262$ & $\$ 4,468,076$ & $\$ 329,512$ & $\$ 3,987,093$ & $\$ 395,836$ & $\$ 4,789,621$ \\
\hline \multicolumn{7}{|c|}{ Photovoltaic - Two Axis Tracking } \\
\hline $\begin{array}{l}\text { Community } \\
\text { Perspective }\end{array}$ & $-\$ 30,216$ & $-\$ 1,470,977$ & $\$ 66,080$ & $-\$ 35,071$ & $-\$ 116,678$ & $-\$ 2,829,321$ \\
\hline $\begin{array}{l}\text { Utility Perspective } \\
\text { (low fuel scenario) }\end{array}$ & $\$ 187,473$ & $\$ 2,268,418$ & $\$ 137,272$ & $\$ 1,660,997$ & $\$ 222,406$ & $\$ 2,691,108$ \\
\hline $\begin{array}{l}\text { Utility Perspective } \\
\text { (base fuel } \\
\text { scenario) } \\
\end{array}$ & $\$ 297,061$ & $\$ 3,594,442$ & $\$ 254,569$ & $\$ 3,080,283$ & $\$ 325,328$ & $\$ 3,936,468$ \\
\hline $\begin{array}{l}\text { Utility Perspective } \\
\text { (high fuel } \\
\text { scenario) }\end{array}$ & $\$ 426,631$ & $\$ 5,162,231$ & $\$ 380,704$ & $\$ 4,606,524$ & $\$ 457,333$ & $\$ 5,533,731$ \\
\hline \multicolumn{7}{|c|}{ Photovoltaic - Fixed tilt - Remote area upper limit } \\
\hline $\begin{array}{l}\text { Community } \\
\text { Perspective }\end{array}$ & $-\$ 50,032$ & $-\$ 1,095,617$ & $\$ 27,293$ & $-\$ 46,114$ & $-\$ 121,356$ & $-\$ 2,089,970$ \\
\hline $\begin{array}{l}\text { Utility Perspective } \\
\text { (low fuel scenario) }\end{array}$ & $\$ 136,052$ & $\$ 1,646,231$ & $\$ 99,621$ & $\$ 1,205,415$ & $\$ 161,404$ & $\$ 1,952,985$ \\
\hline $\begin{array}{l}\text { Utility Perspective } \\
\text { (base fuel } \\
\text { scenario) }\end{array}$ & $\$ 215,583$ & $\$ 2,608,551$ & $\$ 180,439$ & $\$ 2,183,308$ & $\$ 239,706$ & $\$ 2,900,440$ \\
\hline $\begin{array}{l}\text { Utility Perspective } \\
\text { (high fuel } \\
\text { scenario) }\end{array}$ & $\$ 309,614$ & $\$ 3,746,323$ & $\$ 274,469$ & $\$ 3,321,080$ & $\$ 333,737$ & $\$ 4,038,212$ \\
\hline
\end{tabular}

Table 9: Net Benefit - Solar Photovoltaic Technologies

Figure 2 and Figure 3 show the sensitivity of net benefits to the buyback price for fixed tilt PV (the most financially viable technology) and the remote area upper limit. A buyback price of more than $\$ 0.50 / \mathrm{kWh}$ is required to make renewable energy connection viable for the remote area upper limit. The buyback price must be more than $\$ 1.00 / \mathrm{kWh}$ (over the life of the project) before the utility makes a net loss for the low fuel scenario with the lowest discount rate. The inverse relationship between community and utility returns requires a trade-off between providing sufficient incentive to stimulate 
renewable energy deployment on the one hand, and ensuring total supply cost is reduced on the other hand.

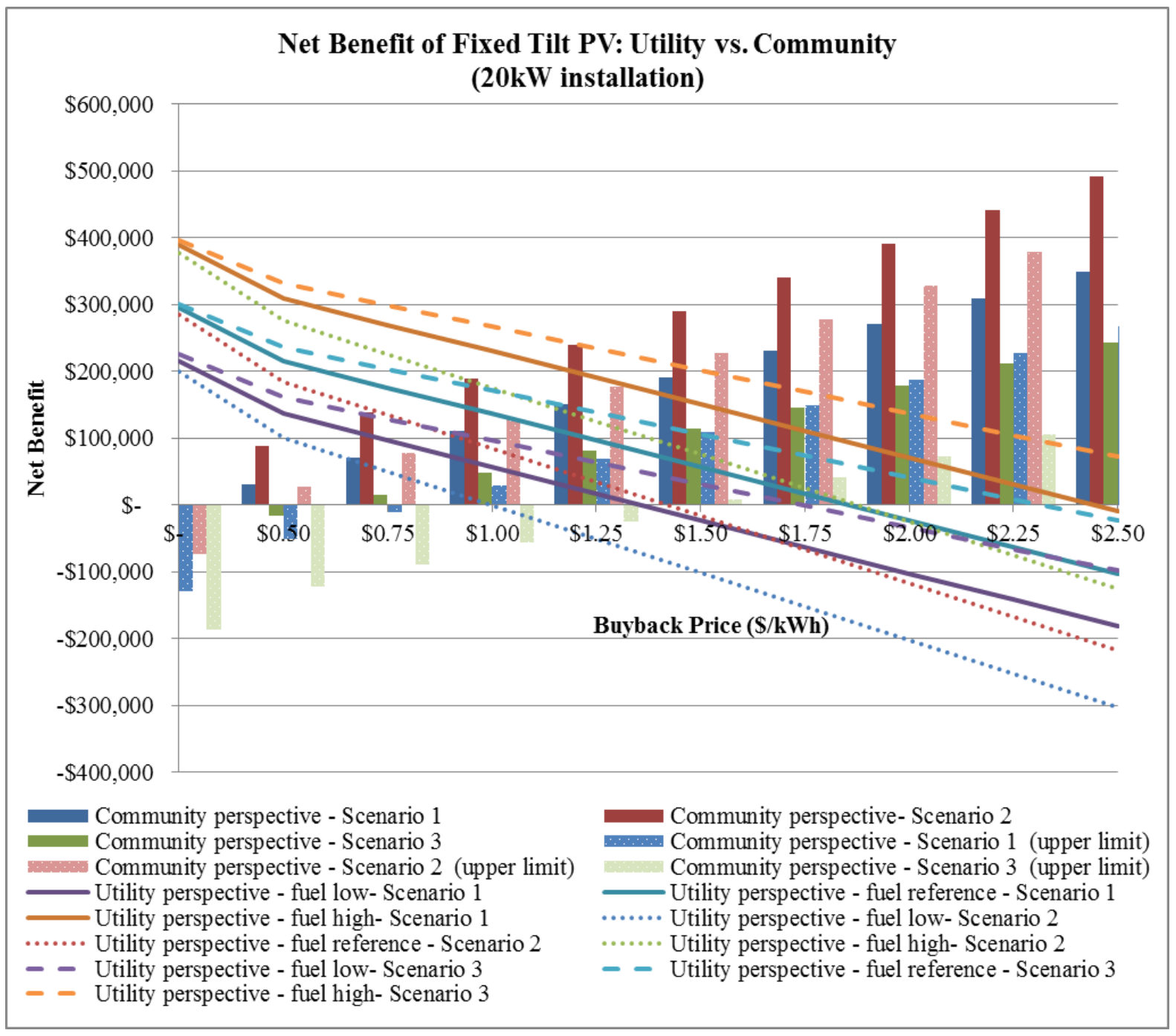

Figure 2: Net Benefit changing buyback price - Fixed tilt PV 20kW installation

Figure 2 and Figure 3 reveal that generation management has a substantial impact on financial viability from a community perspective, but not for the utility. Communities are liable for potential costs that may result from intermittent generation on the network. However, the communities are unable to capture benefits that may arise from improvements to the quality and capacity of the network. In effect, it is a connection charge only required for intermittent renewable technologies and not conventional sources and reflects a need to adapt sunk infrastructure. The question of whether the adaptation of existing public infrastructure should be borne privately is complex, consideration needs to be given to whether the utility, or government, should contribute to this cost. 


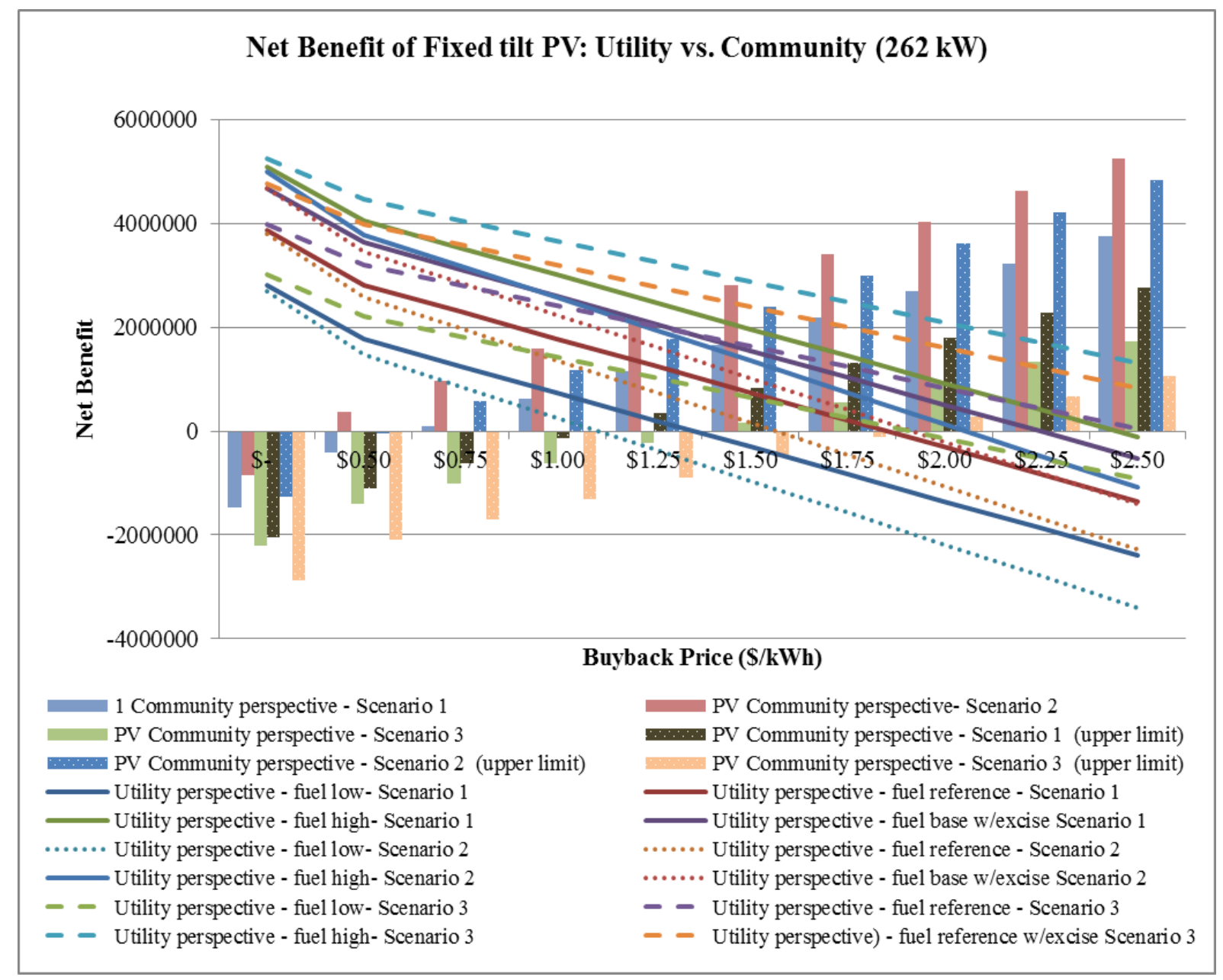

Figure 3: Net Benefit changing buyback price - Fixed tilt PV 262kW installation

The need for generation management is likely to reduce the incentive for communities to exploit the managed hosting capacity. This will delay deployment until storage technologies become more accessible, reliable, cheaper and easier to integrate into grids. Storage has the potential to generate revenue exploit time-of-use tariffs while simultaneously providing the smoothing and ancillary benefits. Storage could have major ramifactions because renewable energy use and storage could be optimised to match periods of high demand and more expensive tariffs (generally during the day in the communities) and then rely on the grid overnight using the off-peak (cheaper) tariff. Thus it is likely to lead to changes in the typical load profile and could result in increasingly stranded assets.

\section{Benefits from deployment}

Financial benefits resulting from renewable energy deployment are considered in Section 5.4. The distribution of those benefits is complicated by cross-subsidies and the private and public benefits associated with deployment.

A range of indirect benefits accrue at the community level. If the deployment of renewables does result in a financial benefit for the community, the additional financial resources could be allocated in a way that the Corporation (and local community) considers would best benefit the community. In effect, renewable energy acts as an "enabler of choice" at the community level. It would enable local action on local issues, prioritised by local Corporations. A number of local issues are outlined below. Underlying these issues is a theme of community independence and pride. Every community wants to be independent of financial support and operate in a way that would best achieve the community social and cultural goals. 
The potential for additional financial resources and lower electricity costs is valued because the rising cost of electricity is regarded as a major driver of cost of living pressure. This pressure has forced residents in Community 1 to purchase less food from the (Corporation owned) store and instead hunt for food due to lack of money. The potential for renewable energy to reduce bills and provide income is highly valued. The availability of jobs and training is also a major issue with the exception of Community 2 whose population is entirely employed by community businesses. Both Community 1 and 3 emphasised the need for funds for training and job creation in the community. The ability to upgrade existing infrastructure (such as old energy intensive fridges and air-conditioning in stores) and subsidising food (to offset rising costs) is also valued because of the existing lack of financial resources to do so. There is also a strong desire to pursue new initiatives that benefit the communities in the long-term. For example, Community 1 hoped to pursue eco-tourism which required higher quality accommodation, and an information and cultural centre. This will increase demand for electricity (and thus cost to the community). If installation can be used to offset those costs while also reducing the cost (per unity of energy) this will benefit the community. Deployment is likely to increase resources at the community level which will enable local action to improve livelihoods and community development, increase community independence from government and greater collaborative decision making. Integration of renewables has been shown to have livelihood benefits internationally [8].

\section{Barriers}

The financial analysis indicates that there are mixed incentives for renewable energy deployment especially for larger systems that require generation management. Nevertheless, installing fixed tilt PV will save all stakeholders money. The lack of deployment in examined communities suggests nonfinancial barriers are also frustrating deployment. Through a series of semi-structured barriers associated with human and financial capacities were identified as shown in Figure 4.

\section{Key Barriers}

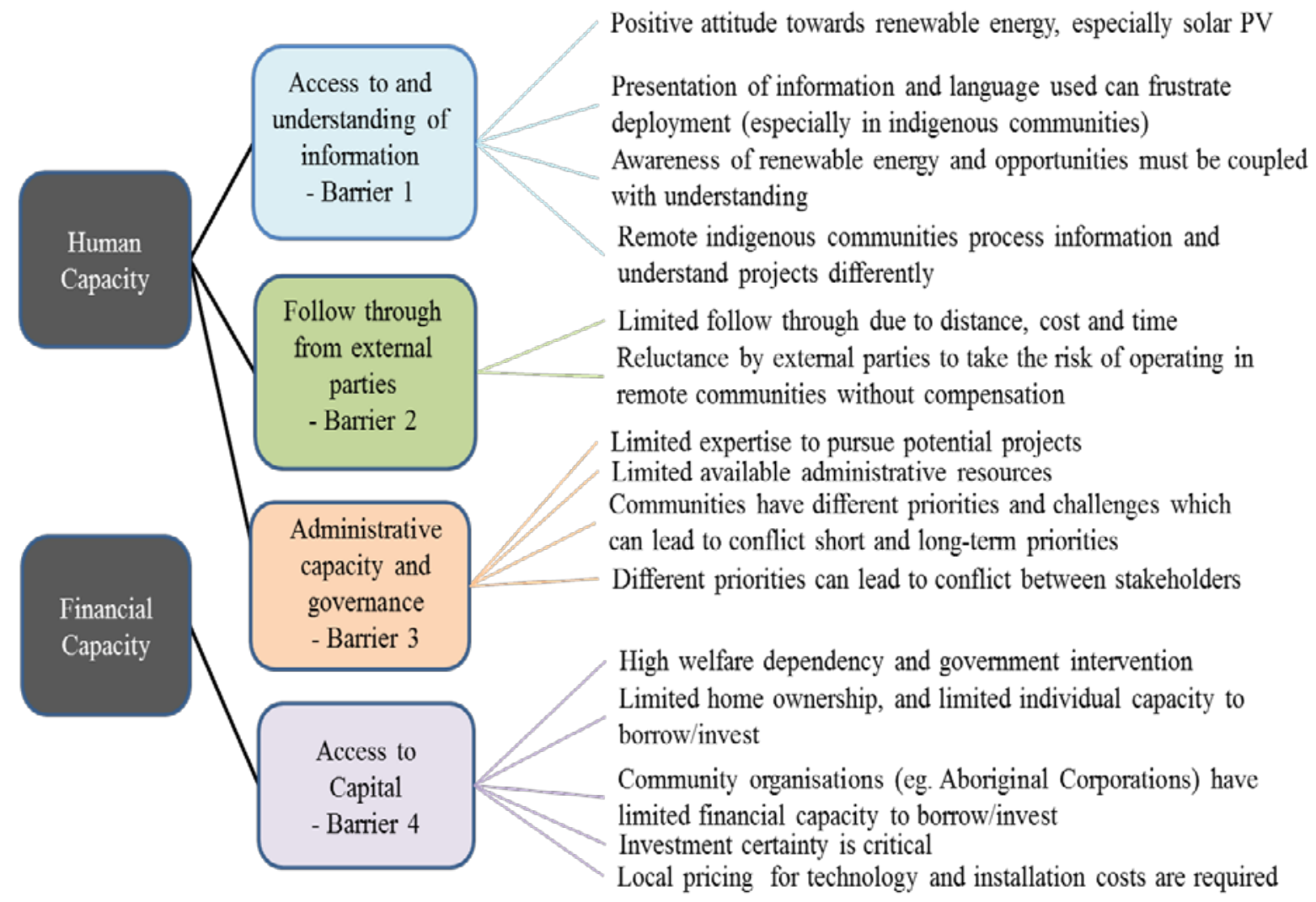

Figure 4: Barriers to Deployment 


\section{Barrier 1: Access to and understanding information}

The semi-structured interviews revealed that general attitudes toward renewable energy and solar PV, in particular, are positive. This positive attitude is likely due to the "Bushlight" program ${ }^{5}$ which operates in the region and is well regarded.

The way in which information is expressed, however, is perceived as a barrier to understanding. The lack of visual presentation of key information about renewables, is an issue because "aboriginal people are more visual people". Presenting key information in a more visual format and relying on communities' ability to seek further information was identified as a simple way to erode this barrier. Technical language also poses an information hurdle. Issues associated with network integration, the use and role of generation management, hosting capacity and technology capacity factors need to be presented in a way that is understandable. Failure to do so can lead to misunderstanding and impede installation. Addressing informational barriers is a dynamic process of forging an information pathway that equips decision makers and stakeholders with sufficient information to make a decision. Addressing this barrier requires recognition of local information challenges, working with community leaders as they work through participatory decision making.

\section{Barrier 2: Follow through from extermal parties}

Poor follow through from external parties reflects previous experience with installers and people in the renewable energy industry. Consequently, communities are reluctant to allocate resources to investigate renewable energy. Remoteness and willingness of external parties to accept perceived uncertainty associated with remote indigenous communities contributes to this barrier. Remote indigenous communities have different (more participatory) decision making process, system sizes, remoteness, socio-economic factors and ownership structures that have traditionally been the focus of installers. It can be difficult to align remote deployment with typical installer business models focussed on short timeframes and quick installations. Cultural considerations and communal decision making also contribute to the uncertainty. A facilitator familiar with indigenous communities, renewable energy, and the electricity industry that has the capacity and willingness to co-ordinate interactions between stakeholders could help overcome this barrier. This is a barrier that is likely to be eroded as familiarity with remote community installations increases.

\section{Barrier 3: Administrative Capacity and Governance}

Administrative capacity and governance relates to the communities' capacity to identify and act on community priorities. In each of the communities examined, Aboriginal Corporations are tasked with governance and administrative responsibilities. Administrators constantly make trade-offs regarding the allocation of their time and skills. Administrative capacity to investigate renewable energy, seek further information, field questions from the community and work through the community decision making process is limited. Consequently, the ability to maintain project momentum is constrained. Ultimately, the opportunity cost of investigating whether to install renewables is critical.

The ability to retain key expertise is a persistent challenge. For example, the Corporation in Community 1 has changed CEOs regularly due to the substantial responsibility of the role and the lack of administrative support. This meant that the Corporation is cautious about pursuing renewables due to the lack of human resources. In Community 3, the challenge is a lack of motivation, willingness or capacity to pursue new projects. In Community 2, the opportunity aligned with community goals of independence and financial viability and so it became a question of whether it is "worth spending time on it". That is, there may be other competing priorities such as improving businesses and investing in job creation. This threshold operates across all communities and can only

\footnotetext{
5 "Bushlight" is a program focussed on providing (and improving) electricity access to small remote aboriginal communities in Queensland, Northern Territory and Western Australia. More information can be obtained from the website: http://www.bushlight.org.au/
} 
be overcome if the benefit is significant (or certain) and increases financial resources. Local knowledge of human resources and the effectiveness of administrative and governance structures is critical. If communities are unwilling or unable to provide the expertise to pursue renewables and work with different stakeholders it may be necessary for an external facilitator familiar with the challenges may be able to take up this role.

\section{Barrier 4: Access to Capital}

None of the Corporations had capital immediately available while all communities face substantial cost of living pressures and limited financial capacity with two communities also having high welfare dependency. Consequently, even if the administrative challenges associated with home ownership mentioned in Section 6.5 can be overcome, it is unlikely that individual residents or households have the capital available. The accessibility of capital is important because renewable energy projects are characterised by high upfront costs and low operating and maintenance costs.

All communities seemed confident about their ability to access capital. When pressed about where that capital could be obtained, the answers differed depending on the community. Community 1 indicated that it may be possible to borrow against the store and secure funding commercially subject to the expected return of renewables suggesting commercial funders should also be the target of information. Community 1 is reluctant to seek funding from government agencies as that "opened the door for intervention" and reduced its ability to operate independently. In contrast, Community 2 indicated that they would target government grants as "there's always money somewhere, you just need to know where to find it". Because all buildings in Community 2 are community owned, there is also potential to raise rents or impose a one-off levy on residents and businesses. However, a one-off levy is not favoured because of the limited ability to pay. An incremental payment period (either preor post-installation) is favoured but does not overcome the challenge of significant upfront costs. Everyone in Community 2 is employed (mainly for minimum wage) by community businesses so they have greater financial resources than the other communities examined. Community 3 was confident about accessing capital but could not provide details about its source or cost suggesting external support may be needed.

Confidence relating to the accessibility of capital is surprising and may reflect historical availability of government funds for indigenous community initiatives. Indirect government programs such as the renewable energy target can also help reduce the capital required thus eroding the access barrier though Federal government policy is uncertain. Nevertheless, there does appear to be difference between confidence in the ability to access funding and the reality of sourcing it.

\section{Barrier 6: Institutional Barriers}

Installing renewable energy in indigenous communities has the potential to reach across government jurisdictions. The lack of communication and cooperation between State and Federal agencies (as well as within them) creates redundancy and limits the ability for effective policy to be developed and acted on. A cooperative and flexible whole of government approach would allow resources to be shared between agencies and allocated more effectively and enable more effective structuring of incentives and distribution of benefits and costs.

General uncertainty about government policy can also be a barrier, especially where policy is intended to incentivise communities to act in a particular way. The role of politics in developing and adapting policy is also challenging. Political priorities can be short-term focused and differ between parties contributing to uncertainty. This issue is not an issue specific to indigenous communities but a wider issue for renewable energy. Uncertainty can lead to discounting the "value" of government led initiatives to reflect the perceived risk 


\section{Barrier 5: Other Barriers}

With the exception of Community 2, housing is owned almost entirely by State Government agencies. In all communities, Aboriginal Corporations own all businesses and non-government buildings. This restricts the ability for residents to install solar without approval.

Vandalism of rooftop panels resulting from rocks thrown on rooftops was a concern for Community 3. This concern was relatively unimportant for the other communities which believed that as a community they could ensure the panels are off limits. That is, if the community could "buy in" to the project sufficiently, collective action may pressure members of the community to refrain from vandalism. Availability of land for deployment is also problematic due to native title and the need to manage cultural heritage. This can increase the cost and time needed for land based deployment.

Network hosting capacity is also an issue as every installation restricts the capacity available to other people. This issue may be particularly troublesome in Community 2 and Community 3 which share a network but wish to install renewables separately. This may be especially important if one community exploits the unmanaged capacity with any additional connections will requiring generation management. Ultimately, there is a substantial first mover advantage potentially causing conflict within and between communities.

A range of qualitative barriers are frustrating deployment. Together the identified barriers impact communities differently and require different strategies to be overcome. However, being aware of the barriers enables strategies and policy to be developed to overcome them.

\section{Conclusion:}

Deployment of renewable energy in remote communities in the Kimberley of Western Australia requires adaptation of traditional methods of incentivising installation. While financial viability is important, it is also necessary to recognise the local context and how it shapes the barriers and benefits likely to arise.

Financial constraints in remote communities are responsible for many of the social challenges and limited deployment. A range of qualitative barriers also frustrate deployment. Using price signals through the buy-back price to encourage installation can be an effective measure given that financial resources are highly valued by communities. However, to be effective they must be structured and framed in light of local barriers.

Installing renewables in remote indigenous communities is a dynamic and stepwise process. As familiarity increases, expectations of benefits are met (or exceeded), and easy installation options are exploited, deployment will increase and barriers will be eroded. Figure $\mathbf{5}$ outlines the process envisaged for the installation of renewables in remote communities.

Adaptation of existing approaches is needed to erode the barriers frustrating deployment. As installation occurs, familiarity with renewable energy will increase, and informational and other barriers will reduce over time. Eventually a point will be reached where deployment is constrained again. At this stage, it will be necessary to again identify the constraint(s) which may include barriers already identified needing to be addressed in a different way or it may be a new challenge. Policy approaches must recognise local barriers and benefits valued at the local level. Remote communities possess their own characteristics, and while the barriers arising across the three communities are broadly similar a broad policy approach is insufficient. All communities valued the prospect of renewables and potential benefits that could derive. The buyback program is a policy instrument with more of a local focus, but it fails to account for qualitative barriers. The utility and governments should recognise the importance of these barriers and develop a pathway to deployment in partnership with remote communities that will stimulate deployment and erode the barriers overtime. 


\section{Installation of Renewables in Remote Communities}

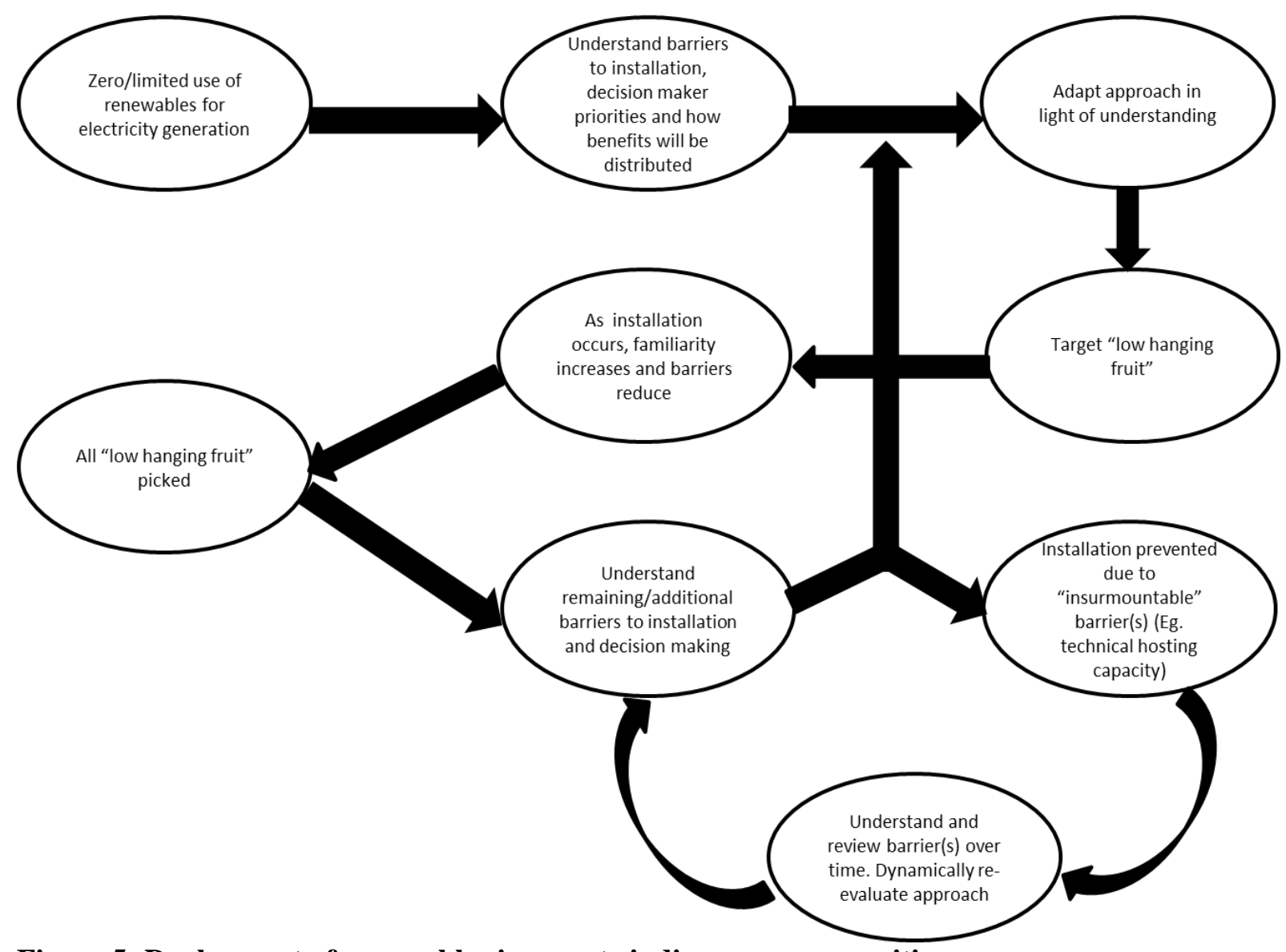

Figure 5: Deployment of renewables in remote indigenous communities

Installation is likely to be led by local Aboriginal Corporations or external stakeholders working with Corporations that have greater access to capital, can overcome administrative issues and have greater administrative and human resources. Household led installations are unlikely, at least in the short term until administrative and capital barriers can be overcome.

All Kimberley communities examined as part of this research are enthusiastic about the potential of renewable energy to provide both immediate and longer term benefits in a way that facilitates independence. Deployment of renewables in remote communities has the potential to help overcome many social challenges while providing direct financial benefits to the distribution utility and communities. The findings are relevant to communities characterised by remoteness, limited human and financial resources and expensive local supply costs irrespective of their location around globe The distribution of benefits and the role of government where both private and public interests are affected is challenging and should be a focus of future research.

\section{Acknowledgements:}

Thanks to Horizon Power which funded and coordinated the field trip to the Kimberley. Particular thanks to Tim Middlehurst formerly of Horizon Power, and Scott Davis, Sam Lovell and Terry Shadforth of Horizon Power for their knowledge and assistance. 


\section{References}

[1] Reiche K, Covarrubia J, Martinot E. Expanding electricity access to remote areas: off-grid rural electrification in developing countries. World Power; 2000. p. 52-60.

[2] Yadoo A, Cruickshank H. The value of cooperatives in rural electrification. Energy Policy. 2010;38:2941-7.

[3] CSIRO. Intelligent Grid: A value proposition for wide scale distributed energy solutions in Australia Australia2009.

[4] Vine E, Hamrin J, Eyre N, Crossley D, Maloney M, Watt G. Public policy analysis of energy efficiency and load management in changing electricity businesses. Energy Policy. 2003;31:405-30.

[5] Byrnes L, Brown C, Foster J, Wagner LD. Australian renewable energy policy: Barriers and challenges. Renewable Energy. 2013;60:711-21.

[6] Verbruggen A, Fischedick M, Moomaw W, Weir T, Nadaï A, Nilsson LJ, et al. Renewable energy costs, potentials, barriers: Conceptual issues. Energy Policy. 2010;38:850-61.

[7] Nalan ÇB, Murat Ö, Nuri Ö. Renewable energy market conditions and barriers in Turkey.

Renewable and Sustainable Energy Reviews. 2009;13:1428-36.

[8] Zerriffi H. Rural Electrification: Strategies for Distributed Generation. Vancouver, British

Columbia, Canada: Springer; 2011.

[9] Krupa J. Identifying barriers to aboriginal renewable energy deployment in Canada. Energy Policy. 2012;42:710-4.

[10] Yadoo A, Gormally A, Cruickshank H. Low-carbon off-grid electrification for rural areas in the United Kingdom: Lessons from the developing world. Energy Policy. 2011;39:6400-7.

[11] Yadoo A, Cruickshank $\mathrm{H}$. The role for low carbon electrification technologies in poverty reduction and climate change strategies: $A$ focus on renewable energy mini-grids with case studies in Nepal, Peru and Kenya. Energy Policy. 2012;42:591-602.

[12] Palit D, Chaurey A. Off-grid rural electrification experiences from South Asia: Status and best practices. Energy for Sustainable Development. 2011;15:266-76.

[13] Winkler H, Simões AF, Rovere ELI, Alam M, Rahman A, Mwakasonda S. Access and Affordability of Electricity in Developing Countries. World Development. 2011;39:1037-50.

[14] Sovacool BK, D'Agostino AL, Bambawale MJ. Gers gone wired: Lessons from the Renewable Energy and Rural Electricity Access Project (REAP) in Mongolia. Energy for Sustainable Development. 2011;15:32-40.

[15] Taele BM, Mokhutšoane L, Hapazari I, Tlali SB, Senatla M. Grid electrification challenges, photovoltaic electrification progress and energy sustainability in Lesotho. Renewable and Sustainable Energy Reviews. 2012;16:973-80.

[16] Hong GW, Abe N. Sustainability assessment of renewable energy projects for off-grid rural electrification: The Pangan-an Island case in the Philippines. Renewable and Sustainable Energy Reviews. 2012;16:54-64.

[17] Bhattacharyya SC. Review of alternative methodologies for analysing off-grid electricity supply. Renewable and Sustainable Energy Reviews. 2012;16:677-94.

[18] Singh A. Renewable energy in the Pacific Island countries: resources, policies and issues. Management of Environmental Quality: An International Journal. 2012;23:254-63.

[19] ABS. Australian Social Trends, April 2013: The 'average' Australian. Canberra, Australia: The Australian Bureau of Statistics; 2013.

[20] ABS. Energy Sources Used by Households. 24/10/2011 ed. Canberra

http://www.abs.gov.au/ausstats/abs@.nsf/Lookup/4602.0.55.001Main+Features4Mar+2011:

Australian Bureau of Statistics; 2011.

[21] BREE. 2014 Australian Energy Update. Canberra: Bureau of Resources and Energy Economics; 2014.

[22] R McLaclan, G Gilfillan, J Gordan. Deep and Persistent Disadvantage in Australia. Productivity Commission Staff Working Paper. Canberra: Australian Government Productivity Commission; 2013. 
[23] KDC. 2011 Census - A Kimberley Perspective. Western Australia: Kimberley Development Commission; 2011.

[24] ABS. 2011 Census data - Kimberley. In: Statistics ABo, editor. Canberra: Australian Government; 2011.

[25] Cook P. Private sector development strategy in developing countries. In: G H, editor. Privatization and market development. Cheltenham: Edward Elgar; 2006.

[26] Horizon Power. Electricity prices and charges (Residential). 2014.

[27] Horizon Power. Electricity prices and charges (Business). 2014.

[28] Burgess RG. In The Field: An Introduction to Field Research. London: Allen and Unwin; 1984.

[29] Mason J. Qualitative Researching. 2nd ed. London: SAGE Publications Ltd; 2002.

[30] Campbell HF, Brown RPC. A multiple account framework for cost-benefit analysis. Evaluation and Program Planning. 2005;28:23-32.

[31] Boardman AE, Greenberg DH, Vining AR, Weimer DL. Cost-benefit analysis: concepts and practice. New Jersey: Prentice Hall; 2001.

[32] John Foster, Liam Wagner, Bratanova A. LCOE models: A comparison of the theoretical framework and key assumptions. Queensland: University of Queensland, Energy Economics and Management Group; 2014.

[33] Wagner L, Foster J. Is There an Optimal Entry Time for Carbon Capture and Storage? A Case Study for Australia's National Electricity Market. Energy Economics Management Group, School of Economics, : The University of Queensland, Australia; 2011.

[34] Alsonso G, Ramon Ramirez J, Palacios J. Economic analysis of the levelized cost of electricity generation. 2006 International Congress on Advances in Nuclear Power Plants (ICAPP'06)2006. p. 1046-50.

[35] Berrie TW. The economics of system planning in bulk electricity supply: 2 - Development of generating plant mix. Electrical Review. 1967:425-8.

[36] Berrie TW. The economics of system planning in bulk electricity supply: 1 - Margins, risks and costs. Electrical Review. 1967:384-8.

[37] Berrie TW. The economics of system planning in bulk electricity supply: appraising the economic worth of alternative projects. Electrical Review. 1967:465-8.

[38] BREE. Australian Energy Technology Assessment 2013 Model Update. Canberra2013.

[39] BREE. Australian energy technology assessment 2012. In: Economics BoRaE, editor. Canberra,

ACT: Bureau of Resources and Energy Economics; 2012.

[40] Skoplaki E, Palyvos JA. On the temperature dependence of photovoltaic module electrical performance: A review of efficiency/power correlations. Solar Energy. 2009;83:614-24.

[41] Rodriguez LC, May B, Herr A, Farine D, O'Connell D. Biofuel excision and the viability of ethanol production in the Green Triangle, Australia. Energy Policy. 2011;39:1951-7.

[42] Horizon Power. Horizon Power Annual Report 2012/2013. Western Australia: Horizon Power; 2013.

[43] Byrnes L. The cost of failing to install renewable energy in regional Western Australia. Queensland, Australia: The University of Queensland, Energy Economics and Management Group; 2014. 